\title{
Effect of Type I and Type II Antioxidants on Oxidative Stability, Microbial Growth, pH, and Color in Raw Poultry Meat
}

\author{
Abdulla Khan, Karin Allen*, Xiaoxi Wang \\ Nutrition and Food Sciences, Utah State University, Logan, USA \\ Email: "karin.allen@usu.edu
}

Received 27 July 2015; accepted 13 December 2015; published 16 December 2015

Copyright @ 2015 by authors and Scientific Research Publishing Inc.

This work is licensed under the Creative Commons Attribution International License (CC BY). http://creativecommons.org/licenses/by/4.0/

(c) (i) Open Access

\begin{abstract}
Meat color is an intrinsic property that plays a major role in consumer's perception. Lipid oxidation by-products as well as free iron can adversely affect meat color. This study was to compare the effect of Type I (radical quenching) antioxidants eugenol and rosmarinic acid (RA) to that of Type II (metal chelating) antioxidants milk mineral (MM), phytate, and sodium tri-polyphosphate (STPP) in raw ground chicken patties packed with a single layer of polyvinylchloride (PVC) overwrap. Packaged patties were stored at $4^{\circ} \mathrm{C}$ and analyzed on $0,1,4,7$, and 10 days for $\mathrm{pH}$, surface color, extent of lipid oxidation, oxymyoglobin content, and microbial load. Color stability was measured using Hunter MiniScan calorimeter $\left(L^{*}, a^{*}, b^{*}\right.$ values). An effect was observed in $L^{*}$ values $(P<0.05)$ of meat color between treatments due to the type of antioxidant. Lightness values for STPP and phytate were low and differed $(P<0.05)$ from eugenol and rosmarinic acid. Milk mineral effectively preserved fresh color and slowed lipid oxidation in chicken patties by day 10 . Aerobic plate counts increased over the entire testing period while values for lightness, redness, yellowness and chroma decreased indicating an increase in $\mathrm{pH}$ favored microbial spoilage of the meat or vice versa. By day 10, eugenol and $M M$ were more effective and significantly different $(\mathrm{P}<$ 0.05) than STPP in controlling lipid oxidation measured as thiobarbituric acid reactive substances $(0.198 \mathrm{mg} / \mathrm{kg}, 0.198 \mathrm{mg} / \mathrm{kg}$, and $0.268 \mathrm{mg} / \mathrm{kg}$, respectively). A positive correlation $(\mathrm{r}=0.24, \mathrm{P}<$ 0.005) between lipid oxidation and color saturation was observed indicating that poultry color darkened with increasing lipid oxidation levels.
\end{abstract}

\section{Keywords}

Poultry Color, Antioxidants, Myoglobin Oxidation, Lipid Oxidation, Metal Chelation

\footnotetext{
${ }^{*}$ Corresponding author.
}

How to cite this paper: Khan, A., Allen, K. and Wang, X. X. (2015) Effect of Type I and Type II Antioxidants on Oxidative Stability, Microbial Growth, pH, and Color in Raw Poultry Meat. Food and Nutrition Sciences, 6, 1541-1551. 


\section{Introduction}

Meat color is a result of the myoglobin pigment. The oxidation state of the oxygen binding molecule myoglobin dictates the color changes in meat. Meat pigments that can influence color are deoxymyoglobin (DMb), oxymyoglobin $(\mathrm{OMb})$, and metmyoglobin (MMb). Poultry meat has low percent myoglobin when compared to other red meats, but it is of equal importance in maintaining color [1]-[3]. Color ranges from light pink to light red for fresh poultry meat that has OMb, but when it oxidizes to MMb, the color changes to light brown [4]. In some cases, myoglobin oxidation occurs rapidly and this may lead to lipid oxidation and color loss. By-products of lipid oxidation can directly interact with myoglobin in poultry meat leading to color change [5]. Iron catalyzed lipid oxidation can accelerate color loss in poultry by the same mechanism as that which occurs in beef, essentially due to structural similarity in myoglobin sequence [5].

Ground meat becomes rancid and changes color faster than whole meat cuts due to the grinding process where it is exposed to air, surface microflora coming in contact to previously intact muscle, and the disruption of intra-cellular membranes, resulting in loss of enzymes and other reductants that can slow the oxidation process [6]. Addition of antioxidants during meat processing can reduce the extent of oxidation and color loss [7] [8]. Several types of antioxidants ranging from natural to synthetic can be added depending on their mechanism of action and consumer demands. Plant derived polyphenols act as potential antioxidants and antimicrobials [9]. Free radical scavenging activity of type I antioxidants coupled with their reactivity as hydrogen or electron donating agents and their interference in the propagation step of the oxidation cycle is of considerable importance [10]. Type II antioxidants act as metal chelating agents by binding to metals like iron and copper, thereby stabilizing a non-redox active form of the metal and inactivating lipid oxidation in the initiation step [10].

The antioxidants used in this study were eugenol, rosmarinic acid, phytate, milk mineral, and sodium tri-polyphosphate (STPP). They can be classified into two types based on how they act: Type I—radical quenching (eugenol, rosmarinic acid), and Type II—metal-chelating (phytate, milk mineral, and sodium tri-polyphosphate) antioxidants. Eugenol, which is the main component in cloves, acts as an antimicrobial and is believed to prevent lipid oxidation [11]. Rosmarinic acid is a spice derived antioxidant used in medicine for its antifungal and antimicrobial activity across the world and it is widely accepted to exhibit highest antioxidant activity [12]. Phytate, or phytic acid, is a food derived phosphate found in nuts and grains which can act as a chelating agent exhibiting its antioxidant property [13]. Milk mineral, a fine white powder, is a by-product of the production of whey protein concentrates obtained by purifying and drying of ultrafiltration permeate of whey. Major components of milk mineral are mineral fraction with calcium and phosphorus along with trace amounts of proteins and fat [14]. STPP is a colorless inorganic compound primarily added to foods for its water holding capacity [15].

Chemical properties of poultry meat such as breed, age, composition of macronutrients and physical factors affecting meat quality have been extensively studied [16]. Similarly, antioxidant properties and their behavior in beef have been highly researched, but fewer studies exist that compare the effect of the different antioxidant types [17]. Based on previous studies, Type I antioxidants were used at a level of $0.05 \%$ by weight and similarly Type II antioxidants were used at $0.5 \%$ by weight. The aim of this study was to compare the effect of Type I and Type II antioxidants on the extension of quality characteristics (color stability, $\mathrm{pH}$ and lipid peroxidation) of raw chicken patties packaged in polyvinylchloride (PVC) overwrap. Susceptibility of the patties to microbial spoilage was also investigated.

\section{Materials and Methods}

\subsection{Treatments}

STPP was obtained from Fisher Scientific (Fairlawn, NJ, USA). Milk mineral (TruCal D50 Milk Calcium Complex) obtained from Glanbia (Monroe, WI, USA). Rosmarinic acid (97\%), phytic acid (dodecasodium salt hydrate, 90\%), and eugenol (99\%) were obtained from Sigma Scientific (St. Louis, MO, USA).

\subsection{Preparation of Ground Chicken}

Previously frozen USDA Grade-A quality chicken thigh and breast pieces (frozen no more than 2 months) were purchased in retail packaging from local retail grocery store in Logan, UT. They were delivered to the Utah State University meat lab and used in preparation of ground chicken on the same day. Visible fat was trimmed off and equal portions of thigh and breast pieces were prepared by coarsely $(0.60 \mathrm{~cm}$ plate) then finely $(0.32 \mathrm{~cm}$ 
plate) grinding through a Hobart grinder model 4125 (Hobart Mfg. Co., Troy, OH, USA). Chicken was fed directly through the grinder and collected immediately for further grinding or mixing with antioxidant treatments. The grinding process took 1 - 2 minutes per treatment, and the entire process was completed within 20 minutes of initial (coarse) grinding. Two 3-ml spectrophotometer cuvettes were filled completely with the ground chicken and later used to obtain reference reflectance spectra (see following section). Thousand gram portions of ground chicken were mixed separately in a Hobart grinder with either $5 \mathrm{~g}$ MM, STPP, or phytate (0.5\%) or $0.5 \mathrm{~g}$ eugenol or RA (0.05\%) [17]. Type I antioxidants used were eugenol and RA, and Type II antioxidants were MM, STPP, and Phytate. For this study, all Type II antioxidants were examined at $0.5 \%$ to determine whether they can exhibit any antioxidant effects at these lower levels. Ground chicken alone (control) and ground chicken + antioxidant mixtures (treatment samples) were then re-ground through the fine plate. Five patties were prepared for each treatment by shaping $130 \mathrm{~g}$ portions using a circular form from a Hollymatic patty machine (Hollymatic Corp., Park Forest, IL, USA). Patties were then placed on 13 x $13 \mathrm{~cm}$ square of Filtrete washable furnace filter (3M Center, St. Paul, MN, USA) that had been wrapped in a single layer of PVC film (Koch, Kansas City, MO, USA; $\mathrm{O}_{2}$ permeability $=8400 \mathrm{~cm}^{3} /\left(24 \mathrm{~h} \cdot \mathrm{m}^{2} \cdot\right.$ atm. $)$ at $23^{\circ} \mathrm{C}$; water vapor transmission $=83 \mathrm{~g} /\left(24 \mathrm{~h} \cdot \mathrm{m}^{2}\right)$ at $23^{\circ} \mathrm{C}$ and 50\% relative humidity). Patties and filters were kept in Cryovac 4L Supermarket Trays and wrapped in an additional layer of PVC film, so both the top and bottom surfaces of the patty were in contact with a single layer of PVC, allowing both surfaces sufficient contact with oxygen to bloom. Patties were held at $4^{\circ} \mathrm{C}$ for 10 days and analyzed on $0,1,4,7$, or 10 days. Five complete replicates were performed. After samples were taken for day 0 analyses, the remaining ground chicken was packaged in quart-sized Ziploc freezer bags (S.C. Johnson and Son, Inc., Racine, WI, USA) and frozen $\left(-10^{\circ} \mathrm{C}\right)$ to hold for determination of iron (Ferrozine assay) on dry ash and fat content of tissue.

\subsection{Oxymyoglobin Determination}

Proportion of OMb to MMb was measured spectrophotometrically using a Shimadzu UV-Vis 2600/2700 spectrophotometer with a reflectance attachment (Shimadzu Scientific Instruments, Inc., Columbia, MD, USA). $\mathrm{OMb}$ content was determined based on the presence of the characteristic reflectance minima at 545 and $580 \mathrm{~nm}$ [18]. For each sample of freshly ground reference chicken, 3-ml cuvettes were prepared by packing in ground chicken tightly to exclude air, and then a spectral scan was performed from 450 to $650 \mathrm{~nm}$. Relative loss of $\mathrm{OMb}$ was determined by comparing the ratio of $\mathrm{OMb}$ to $\mathrm{MMb}$ in each sample to the initial ratio of the freshly ground chicken [19]. Reflectance spectra for samples were measured in duplicate.

\subsection{Color Measurement}

$L^{*}, a^{*}$ and $b^{*}$ values were measured using a HunterLab MiniScan portable colorimeter (Reston, VA, USA) with a $5 \mathrm{~mm}$ diameter aperture, set to use illuminant D-65. The colorimeter was standardized through a single layer of PVC film using both white and black standard tiles. Three-color measurements were taken for each patty. Hue angle (true redness) was calculated as [arctangent ( $\left.\left.\mathrm{b}^{*} / \mathrm{a}^{*}\right)\right]$, and chroma (color saturation) was calculated as $\sqrt{\left(a^{2}+b^{2}\right)}$ [20].

\section{5. $\mathrm{pH}$ Measurement}

A portable pH meter (HANNA Instruments HI99161, Ann Arbor, MI, USA) fitted with a semi-solid food probe was used to measure $\mathrm{pH}$. The $\mathrm{pH}$ probe was inserted directly in to the meat patty and held until $\mathrm{pH}$ reading was constant. For each sample three readings were taken.

\subsection{Thiobarbituric Acid Reactive Substances}

Thiobarbituric acid reactive substances (TBARS) were analyzed as described by [21]. In brief, $1.0 \mathrm{~g}$ ground chicken cores were mixed with $3.0 \mathrm{ml}$ of stock solution containing $0.375 \%$ thiobarbituric acid, $15 \%$ trichloroacetic acid, and $0.25 \mathrm{~N} \mathrm{HCl}$. The mixture was heated for $10 \mathrm{~min}$ in a boiling water bath $\left(100^{\circ} \mathrm{C}\right)$ to develop a pink color, which was cooled in tap water and then centrifuged (3148 X g; Beckman Coulter, Inc. Indianapolis, IN). The absorbance of the supernatant was measured at $532 \mathrm{~nm}$ using a Shimadzu UV-Vis 2600/2700 spectrophotometer (Shimadzu Scientific Instruments, Inc., Columbia, MD, USA). TBA values (mg malondialdehyde/kg of 
meat) were calculated using an extinction coefficient of $156,000 / \mathrm{M} \cdot \mathrm{cm}$.

\subsection{Microbial Load}

Total aerobic counts (TAC) were measured based on AOAC method 990.12. Briefly, $10 \mathrm{~g}$ of sample was stomached in $90 \mathrm{ml}$ Butterfield's phosphate diluent, then further diluted and plated $(1 \mathrm{ml})$ on petrifilm aerobic count plates (3M Corporation, St. Paul, MN, USA) according to the manufacturer instructions. Plates were incubated at $32^{\circ} \mathrm{C}$ for $48 \mathrm{~h}$ then counted and interpreted as per the manufacturer's guidelines and expressed as $\mathrm{CFU} / \mathrm{g}$. All samples were plated in duplicate.

\subsection{Iron Determination}

To determine the iron content in samples, samples were dry ashed then analyzed using the Ferrozine assay [22]. Briefly, $5 \mathrm{~g}$ of dry sample was taken into porcelain crucibles and accurately weighed, then heated on a hot plate until the samples were well charred and stopped smoking. Crucibles were placed in a $550^{\circ} \mathrm{C}$ muffle furnace (Thermo Fisher Scientific Inc., Waltham, MA, USA) until the ash was white (for $24 \mathrm{~h}$ ), then the samples were cooled in a desiccator and weighed to determine the ash percentage. Then ash was dissolved in a small amount of $1 \mathrm{~N} \mathrm{HCl}$ and diluted to $50 \mathrm{ml}$ with $0.1 \mathrm{~N} \mathrm{HCl}$ for iron determination. $0.5 \mathrm{ml}$ of the diluted sample was taken into $10 \mathrm{ml}$ test tubes and $1.250 \mathrm{ml}$ ascorbic acid $(0.02 \%$ in $0.2 \mathrm{~N} \mathrm{HCl})$ was added and vortexed and set for $10 \mathrm{~min} .2$ $\mathrm{ml}$ of $30 \%$ ammonium acetate was added to the test tube vortexed again and $1.250 \mathrm{ml}$ of Ferrozine (1 mM in water) was added and vortexed and set in dark for 15 min for color development. Absorbance of the solution was measured at $562 \mathrm{~nm}$ using a Shimadzu UV-Vis 2600/2700 spectrophotometer (Shimadzu Scientific Instruments, Inc., Columbia, MD, USA). A standard curve (absorbance vs. concentration) was plotted with appropriate concentrations $(0.05,0.1,0.5,1,2,4,6,8$ and $10 \mu \mathrm{g} \cdot \mathrm{iron} / \mathrm{ml})$ and concentration of samples was determined.

\subsection{Fat Analysis}

Fat content in chicken samples was determined using modified Folch method using chloroform-methanol extraction [23] [24]. Briefly, frozen samples were dried using liquid nitrogen. Dry powdered $1.0 \mathrm{~g}$ sample was taken into $50 \mathrm{ml}$ centrifuge tube (Becton Dickinson Labware, Franklin Lakes, NJ, USA) and $3.2 \mathrm{ml}$ of deionized water was added and vortexed. To this $8 \mathrm{ml}$ of methanol and chloroform each were added and vortexed for 2 min followed by $4 \mathrm{ml}$ addition of deionized water and vortexing for $30 \mathrm{sec}$. Samples were centrifuged at 3500 rpm for $10 \mathrm{~min}$ then $4 \mathrm{ml}$ of chloroform extract was pipetted into $10 \mathrm{ml}$ culture tubes and evaporated on a heating block in fume hood for 15 min. Dry fat residue with small amounts of solvent left in it was kept in $101^{\circ} \mathrm{C}$ oven until completely dry. Dry weight of the fat residue was determined and converted to percent fat.

\subsection{Statistical Analysis}

Analysis of variance (repeated measures) was performed using the proc mixed function in SAS version 9.4 (SAS Institute, Inc., Cary, NC, USA). TBA values, chroma, hue angle, and $\mathrm{L}^{*}, \mathrm{a}^{*}, \mathrm{~b}^{*}$ values were evaluated as a split-plot design, with antioxidant type as whole-plot factor and time as sub-plot factor. Proc mixed function was used with treatments, time and their interaction as fixed factors and replicate as random factor. $95 \%$ statistical significance level $(\alpha=0.05)$ was used. Post hoc mean comparison and Pearson correlation coefficients to see the relationships between different properties were made using the Tukey-Kramer adjustment [17].

\section{Results and Discussion}

Samples analyzed on day 0 for iron content and percent fat were within normally accepted levels [25] [26]. Average ash percentage was 0.92 and average free iron present was $0.89 \mu \mathrm{g} / \mathrm{g}$ of meat. The average fat content for chicken used in this study was $6.76 \%$. A summary of the significant differences between treatments based on the average values for each attribute for all six treatments is given in Table 1. A detailed discussion for each characteristic follows.

\subsection{Chicken Color}

A significant effect $(\mathrm{P}<0.05)$ of treatment was seen for $\mathrm{L}^{*}$ values. Based on the International Commission on 
Table 1. Pooled means (over 7 days) for examined characteristicsof raw ground chicken patties.

\begin{tabular}{cccccccc}
\hline Treatment & $\mathrm{L}^{*}$ & $\mathrm{~b}^{*}$ & $\mathrm{a}^{*}$ & Hue-angle & TBA & TAC & pH \\
\hline Control & $47.261^{\mathrm{bc}}$ & 12.228 & $0.964^{\mathrm{b}}$ & $85.546^{\mathrm{a}}$ & $0.279^{\mathrm{c}}$ & 4.69 & $6.29^{\mathrm{a}}$ \\
$0.05 \%$ Eugenol & $46.886^{\mathrm{bc}}$ & 11.810 & $0.609^{\mathrm{ab}}$ & $87.096^{\mathrm{a}}$ & $0.198^{\mathrm{a}}$ & 4.85 & $6.29^{\mathrm{a}}$ \\
$0.5 \%$ MM & $47.578^{\mathrm{c}}$ & 11.752 & $0.638^{\mathrm{ab}}$ & $86.846^{\mathrm{a}}$ & $0.198^{\mathrm{a}}$ & 4.88 & $6.25^{\mathrm{a}}$ \\
$0.5 \%$ Phytate & $46.042^{\mathrm{ab}}$ & 11.693 & $0.539^{\mathrm{a}}$ & $87.254^{\mathrm{b}}$ & $0.210^{\mathrm{ab}}$ & 5.13 & $6.53^{\mathrm{b}}$ \\
$0.05 \%$ RA & $47.181^{\mathrm{bc}}$ & 11.929 & $0.718^{\mathrm{ab}}$ & $86.592^{\mathrm{a}}$ & $0.268^{\mathrm{bc}}$ & 4.45 & $6.28^{\mathrm{a}}$ \\
$0.5 \%$ STPP & $45.176^{\mathrm{a}}$ & 11.520 & $0.694^{\mathrm{ab}}$ & $86.492^{\mathrm{a}}$ & $0.247^{\mathrm{abc}}$ & 4.97 & $6.48^{\mathrm{b}}$ \\
SEM & 0.370 & 0.098 & 0.060 & 0.124 & 0.015 & 0.10 & 0.05 \\
P-values & 0.0001 & 0.1061 & 0.0401 & 0.0191 & 0.0002 & 0.079 & 0.0001 \\
\hline
\end{tabular}

Note: Values not sharing the same letter within a column are significantly different $(\mathrm{P}<0.05)$.

Illumination (CIE) lightness standard values [27], all of the samples except 0.5\% STPP fell within the "normal" range on day $0\left(48<\mathrm{L}^{*}<51\right)$, whereas on day 10 all samples were in the range of "darker than normal" ( $\mathrm{L}^{*}<$ 47). A significant effect $(\mathrm{P}<0.001)$ due to day was observed within the treatment, as expected (Table 1 , Table 2). Overall lightness values for Type II antioxidants STPP $(\mathrm{P}<0.05)$ and phytate $(\mathrm{P}>0.05)$ were lower than samples treated with Type I antioxidants eugenol, and rosmarinic acid. Even though milk mineral was not different $(P>0.05)$ from eugenol, rosmarinic acid, or the control it had the highest average lightness $\left(L^{*}=47.58\right)$ value meaning it was lighter in color (Table 1 ). Hunter a* values decreased from day 0 to day 4 but a significant difference $(\mathrm{P}<0.05)$ was seen on day 7 in all treatments (Table 1 , Table 3$)$. Average phytate $\mathrm{a}^{*}$ values were different $(\mathrm{P}<0.05)$ from the control, while STPP, RA, eugenol, and milk mineral average a* values showed no difference (Figure 1). Eugenol, MM, and phytate had higher values for hue angle after 10 days, indicating a loss of true redness over time in these samples (Table 4).

Results show that $\mathrm{L}^{*}$ and $\mathrm{b}^{*}$ values strongly influenced color in all cases, which can be seen from the hue angle data (Table 4). Based on the CIE color solid and AMSA color evaluation guidelines [28], hue angle values ranged between $80^{\circ}-95^{\circ}$ indicating the samples remained in the yellowish region of the spectrum (Table 4). Similarly $\mathrm{a}^{*}$ values shifted from red $\left(+\mathrm{a}^{*}\right)$ to green $\left(-\mathrm{a}^{*}\right)$ over time, which was most likely due to loss of OMb. Hence net effect on patty color was a shift from initial yellowish-orange tinge to yellowish-green undertone. This change was identified instrumentally, but was less obvious to observe visually compared to the darkening of the samples (Table 2). This is consistent with previous studies [29], where no improvement in $\mathrm{a}^{*}$ redness values in chicken patties was found in the presence of rosemary. First difference $(\mathrm{P}<0.05)$ in hue angle (as compared to day 0 ) was observed on day 7 for MM and on day 10 for eugenol, whereas for all other treatments a noticeable difference was not observed even on day 10 (Figure 2).

\subsection{TBARS}

TBARS values tended to increase for eugenol, MM, phytate, and RA ( $>0.05)$, while significant increases were seen for STPP $(\mathrm{P}<0.05)$ during the storage period. However, all the values were under $1 \mathrm{mg} \cdot \mathrm{MDA} / \mathrm{kg}$ of meat, suggesting the samples would still be acceptable from a sensory standpoint [30]. Antioxidants MM, eugenol and phytate were relatively more effective in preventing lipid oxidation than STPP and rosmarinic acid when compared to control values ( $\mathrm{P}>0.05$; Table 5; Figure 3). Because of their spice derived antioxidant nature, eugenol and rosmarinic acid have a distinctive aroma which may have masked rancidity in these respective patties. This is consistent with previous studies, where a strong spice or herb aroma can be considered a negative sensory aspect from consumer point of view [11]. Milk mineral was the most effective in preventing lipid oxidation (Table 1; Table 5). TBA value for STPP was significantly $(\mathrm{P}<0.05)$ different from day 0 to day 10 indicating higher oxidation byproducts in the samples.

\subsection{Microbial Growth}

A continuous increase in TAC numbers was observed over the storage time period in all the samples. In patties 
Table 2. Lightness values for raw ground poultry patties: time to first significant difference as compared to day 0 and at day 0 and day 10.

\begin{tabular}{|c|c|c|c|}
\hline \multirow{2}{*}{ Treatment } & \multirow{2}{*}{$\begin{array}{c}\text { Days to first } \\
\text { Significant difference }\end{array}$} & \multicolumn{2}{|c|}{ Lightness (L*) } \\
\hline & & Day $0^{\mathrm{B}}$ & Day $10^{\mathrm{B}}$ \\
\hline Ground chicken & ns & $49.10 \pm 1.81 \mathrm{a}$ & $45.89 \pm 1.34$ \\
\hline 0.05\% Eugenol & ns & $48.49 \pm 1.73 \mathrm{a}$ & $45.40 \pm 1.75 a$ \\
\hline $0.5 \% \mathrm{MM}$ & ns & $49.48 \pm 1.95 \mathrm{a}$ & $46.57 \pm 2.66 a$ \\
\hline 0.5\% Phytate & ns & $46.24 \pm 1.26 \mathrm{a}$ & $46.79 \pm 2.30$ \\
\hline $0.05 \%$ RA & ns & $48.74 \pm 2.47 \mathrm{a}$ & $45.09 \pm 1.92$ \\
\hline $0.5 \%$ STPP & ns & $46.20 \pm 2.72 \mathrm{a}$ & $44.65 \pm 2.12$ \\
\hline
\end{tabular}

$\mathrm{STPP}=$ sodium tri-polyphosphate; $\mathrm{RA}=$ rosmarinic acid; $\mathrm{MM}=$ milk mineral. ${ }^{\mathrm{A}}$ : Time point where first significant difference $(\mathrm{P}<0.05)$ occurs as compared to initial reading for each meat system formulation. ${ }^{\mathrm{B}}$ : Values represent mean \pm standard deviation at a given time point $(\mathrm{n}=5)$. Values sharing letters within the column are not significantly different $(\mathrm{P}>0.05)$.

Table 3. Redness (a*) values: time to first significant difference as compared to day 0 and means at day 0 and day 10 .

\begin{tabular}{cccc}
\hline Treatment & $\begin{array}{c}\text { Days to first } \\
\text { significant difference }^{\mathrm{A}}\end{array}$ & Day $0^{\mathrm{B}}$ & Redness (a*) $^{\text {Day } 10^{\mathrm{B}}}$ \\
\hline Ground chicken & 7 & $1.50 \pm 0.66 \mathrm{a}$ & $0.20 \pm 0.43 \mathrm{~b}$ \\
$0.05 \%$ Eugenol & 7 & $1.44 \pm 0.62 \mathrm{a}$ & $-0.48 \pm 0.41 \mathrm{~b}$ \\
$0.5 \%$ MM & 7 & $1.05 \pm 0.89 \mathrm{a}$ & $-0.23 \pm 0.15 \mathrm{~b}$ \\
$0.5 \%$ Phytate & 7 & $0.99 \pm 0.99 \mathrm{a}$ & $-0.17 \pm 0.50 \mathrm{~b}$ \\
$0.05 \%$ RA & 7 & $1.13 \pm 0.52 \mathrm{a}$ & $0.00 \pm 0.38 \mathrm{~b}$ \\
$0.5 \%$ STPP & 7 & $1.18 \pm 0.69 \mathrm{a}$ & $0.11 \pm 0.24 \mathrm{~b}$ \\
\hline
\end{tabular}

STPP = sodium tri-polyphosphate; RA = rosmarinic acid; $\mathrm{MM}=$ milk mineral. ${ }^{\mathrm{A}}$ : Time point where first significant difference $(\mathrm{P}<0.05)$ occurs as compared to initial reading for each meat system formulation. ${ }^{\text {B }}$ : Values represent mean \pm standard deviation at a given time point $(\mathrm{n}=5)$. Values sharing letters within the column are not significantly different $(\mathrm{P}>0.05)$.

Table 4. Hue angle: time to first significant difference as compared to day 0 and means at day 0 and day 10.

\begin{tabular}{cccc}
\hline & Days to first & \multicolumn{2}{c}{ Hue angle in degrees } \\
Treatment & Dignificant difference & Day $0^{\mathrm{B}}$ & $0^{\mathrm{B}}$ \\
\cline { 3 - 4 } Ground chicken & $\mathrm{ns}$ & $83.26 \pm 2.94 \mathrm{a}$ & $99.02 \pm 1.93 \mathrm{a}$ \\
$0.05 \%$ Eugenol & 10 & $83.32 \pm 2.18 \mathrm{a}$ & $91.07 \pm 0.71 \mathrm{~b}$ \\
$0.5 \%$ MM & 7 & $85.12 \pm 3.56 \mathrm{a}$ & $92.13 \pm 3.20 \mathrm{~b}$ \\
$0.5 \%$ Phytate & 10 & $85.43 \pm 4.51 \mathrm{a}$ & $90.08 \pm 2.03 \mathrm{a}$ \\
$0.05 \%$ RA & $\mathrm{ns}$ & $84.84 \pm 3.21 \mathrm{a}$ & $89.47 \pm 1.08 \mathrm{a}$ \\
\hline
\end{tabular}

STPP = sodium tri-polyphosphate; RA = rosmarinic acid; $\mathrm{MM}=$ milk mineral. ${ }^{\mathrm{A}}$ : Time point where first significant difference $(\mathrm{P}<0.05)$ occurs as compared to initial reading for each meat system formulation. ${ }^{\text {B }}$ : Values represent mean \pm standard deviation at a given time point $(\mathrm{n}=5$ ). Values sharing letters are not significantly different $(\mathrm{P}>0.05)$.

treated with eugenol, MM, and phytate there were no significant $(\mathrm{P}>0.05)$ differences observed during the 10 days, whereas in control and patties treated with rosmarinic acid and STPP a noticeable increase was seen on day 10. Even though some of the values on day 7 and all treatments on day 10 have TAC approaching 8-log cfu/g (Table 1; Table 6), their average count was well below the point where fresh poultry exhibits off odors and sliminess due to bacterial spoilage [31]. 


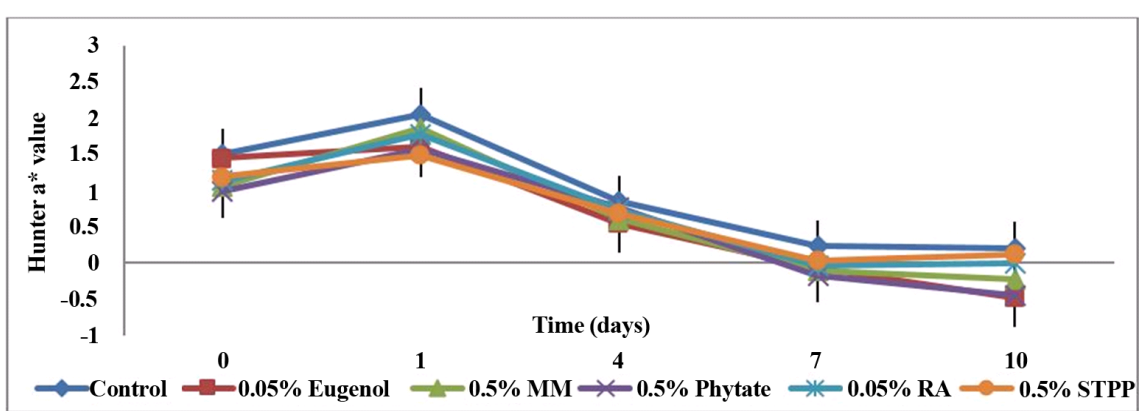

Figure 1. Hunter $\mathrm{a}^{*}$ values in ground chicken patties treated with $0.05 \%$ eugenol, $0.5 \%$ milk mineral, $0.5 \%$ phytate, $0.05 \%$ rosmarinic acid, $0.5 \%$ sodium tripolyphosphate as compared to control. Day effect was seen $(\mathrm{P}<0.0001)$; no trt* day effect was observed $(\mathrm{P}=0.945)$.

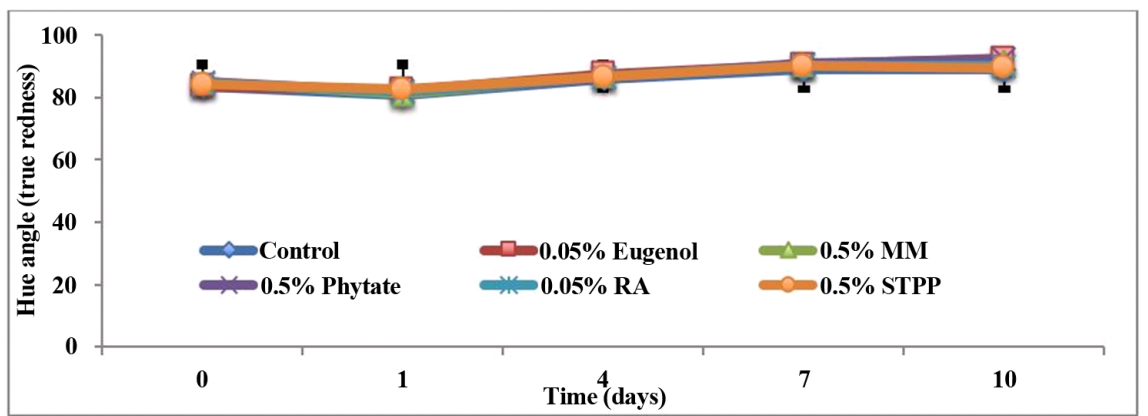

Figure 2. Hue angle values in ground chicken patties treated with $0.05 \%$ eugenol, $0.5 \%$ milk mineral, $0.5 \%$ phytate, $0.05 \%$ rosmarinic acid, $0.5 \%$ sodium tri-polyphosphate as compared to control. Day effect was seen $(\mathrm{P}<0.0001)$; no trt* day effect was observed $(\mathrm{P}=0.299)$.

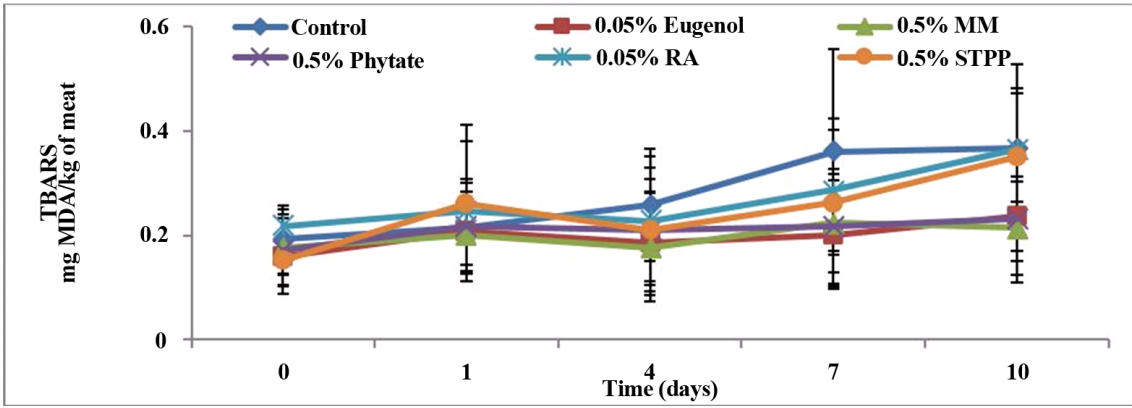

Figure 3. TBA values in ground chicken patties treated with $0.05 \%$ eugenol, $0.5 \%$ milk mineral, $0.5 \%$ phytate, $0.05 \%$ rosmarinic acid, $0.5 \%$ sodium tri poly phosphate (STPP) as compared to control. Day effect was seen $(\mathrm{P}<0.0001)$; no trt* day effect $(\mathrm{P}=0.578)$.

Table 5. TBARS: time to first significant difference as compared to day 0 and means at day 0 and day 10 .

\begin{tabular}{|c|c|c|c|}
\hline \multirow{2}{*}{ Treatment } & \multirow{2}{*}{$\begin{array}{c}\text { Days to first } \\
\text { significant difference }^{A}\end{array}$} & \multicolumn{2}{|c|}{ TBARS } \\
\hline & & Day $0^{\mathrm{B}}$ & Day $10^{\mathrm{B}}$ \\
\hline Ground chicken & ns & $0.19 \pm 0.07 \mathrm{a}$ & $0.37 \pm 0.10 \mathrm{a}$ \\
\hline 0.05\% Eugenol & ns & $0.16 \pm 0.07 \mathrm{a}$ & $0.24 \pm 0.13 a$ \\
\hline 0.5\% MM & ns & $0.18 \pm 0.07 \mathrm{a}$ & $0.21 \pm 0.09 a$ \\
\hline 0.5\% Phytate & ns & $0.17 \pm 0.07 \mathrm{a}$ & $0.23 \pm 0.08 \mathrm{a}$ \\
\hline $0.05 \%$ RA & ns & $0.22 \pm 0.04 \mathrm{a}$ & $0.36 \pm 0.11 \mathrm{a}$ \\
\hline 0.5\% STPP & 10 & $0.15 \pm 0.03 \mathrm{a}$ & $0.35 \pm 0.18 a$ \\
\hline
\end{tabular}

$\mathrm{STPP}=$ sodium tri-polyphosphate; $\mathrm{RA}=$ rosmarinic acid; $\mathrm{MM}=$ milk mineral. ${ }^{\mathrm{A}}$ : Time point where first significant difference $(\mathrm{P}<0.05)$ occurs as compared to initial reading for each meat system formulation. ${ }^{\mathrm{B}}$ : Values represent mean \pm standard deviation at a given time point $(\mathrm{n}=5)$. Values sharing letters are not significantly different $(P>0.05)$. 
Table 6. Total Aerobic Counts: time to first significant difference as compared to day 0 and means at day 0 and day 10 .

\begin{tabular}{cccc}
\hline Treatment & $\begin{array}{c}\text { Days to first } \\
\text { significant difference }\end{array}$ & \multicolumn{2}{c}{ TAC (log·cfu/g) } \\
\cline { 3 - 3 } Ground chicken & 10 & Day $0^{\mathrm{B}}$ & $5.92 \pm 2.05 \mathrm{a}$ \\
$0.05 \%$ Eugenol & $\mathrm{ns}$ & $3.76 \pm 0.95 \mathrm{a}$ & $5.62 \pm 2.04 \mathrm{a}$ \\
$0.5 \%$ MM & ns & $4.25 \pm 0.67 \mathrm{a}$ & $5.76 \pm 1.83 \mathrm{a}$ \\
$0.5 \%$ Phytate & ns & $4.15 \pm 0.95 \mathrm{a}$ & $5.96 \pm 1.75 \mathrm{a}$ \\
$0.05 \%$ RA & 10 & $4.18 \pm 1.36 \mathrm{a}$ & $5.68 \pm 2.03 \mathrm{a}$ \\
$0.5 \%$ STPP & 10 & $3.51 \pm 1.21 \mathrm{a}$ & $6.13 \pm 1.58 \mathrm{a}$ \\
\hline
\end{tabular}

STPP = sodium tri-polyphosphate; RA = rosmarinic acid; $\mathrm{MM}=$ milk mineral. ${ }^{\mathrm{A}}$ : Time point where first significant difference $(\mathrm{P}<0.05)$ occurs as compared to initial reading for each meat system formulation. ${ }^{B}$ : Values represent mean \pm standard deviation at a given time point $(n=5)$. Values sharing letters are not significantly different $(\mathrm{P}>0.05)$.

\section{4. $\mathrm{pH}$}

Measured $\mathrm{pH}$ of all the patties for all treatments was over 6.0 from day 0 (Table 7). Eugenol, rosmarinic acid, STPP, and control had increased $(\mathrm{P}<0.05) \mathrm{pH}$ values by day 10 with respect to day 0 (Figure 4). For MM and phytate $\mathrm{pH}$ did not change notably $(\mathrm{P}>0.05)$ from day 0 to day 10 , which indicates an effect due to these treatments (Table 1; Table 7). In comparison, low pH values were recorded for MM while phytate and STPP had higher $\mathrm{pH}$ values throughout the testing period.

\subsection{Oxymyoglobin Stability}

Relative loss of OMb was not significant $(\mathrm{P}>0.05)$ for any of the treatment samples, indicating that its concentration did not change during storage. This result is in agreement with previously reported results [32], where the concentrations of $\mathrm{Mb}$ and $\mathrm{MMb}$ percentage in chicken breast samples did not change $(\mathrm{P}>0.05)$ over 10 days.

\subsection{Overall Discussion}

The differences in $\mathrm{pH}$, lipid oxidation and color seen in the current study can be explained based on the amounts of endogenous catalysts like myoglobin, free ionic iron reducing compounds, antioxidants that determine the extent of lipid oxidation. Reference [32] reported raw chicken is more resistant to oxidative changes than other meats, where this stability is influenced by iron chelating ability, the presence of anti- or pro-oxidants, and the relative concentration of ionic iron present [33].

It has been suggested [34] that in poultry, low pH is associated with low water-holding capacity and an increased shelf life. In the current study, the two Type II metal chelating antioxidants STPP and phytate are believed to have high water holding capacity initially due to an abundance of phosphate groups, which increase $\mathrm{pH}$. This resulted in initial higher $\mathrm{L}^{*}$ values, but later the patties treated with STPP and phytate had lower L* values and higher $\mathrm{pH}$ when compared to other antioxidant treatments. Reference [35] reported an inverse correlation between use of phosphates and reduction of gram-negative bacteria in fresh meats. This is in line with the strong odors observed informally during testing at day 7 in the current study, most likely the result of microbial growth and lipid oxidation. Type I antioxidants eugenol and rosmarinic acid were more effective in preventing microbial growth $(<6 \mathrm{log} \cdot \mathrm{cfu} / \mathrm{g})$ and strong off odors. Significant effect $(\mathrm{P}<0.05)$ due to the antioxidant type was observed in log cfu/g values, mainly between patties treated with phytate and rosmarinic acid. Patties with rosmarinic acid showed the lowest levels of microbial growth, which is consistent with previous findings that spice derived antioxidants inhibit microbial growth [12]. Conversely, eugenol was more effective in preventing lipid oxidation than rosmarinic acid, most likely due to accumulation of eugenol in the lipid phase due to its low water solubility [17]. MM effectively maintained desirable color and $\mathrm{pH}$ in chicken patties and prevented lipid oxidation by directly chelating the free iron. In the current study STPP was not as effective as phytate and MM in controlling lipid oxidation and maintaining color. This is in agreement with previous results [14], where it was suggested that orthophosphates, which are not effective metal chelators, are released from STPP due to the action of natural phosphatase enzymes present in raw meats. 


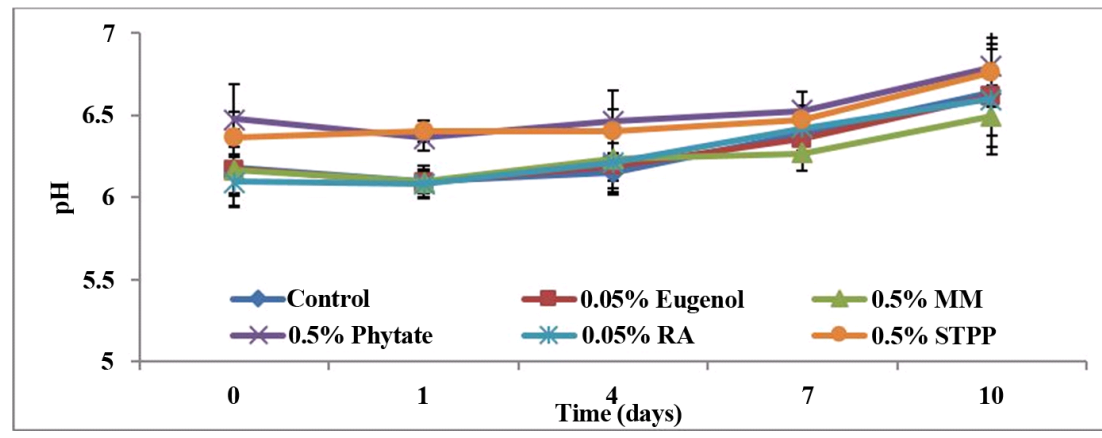

Figure 4. $\mathrm{pH}$ values in ground chicken patties treated with $0.05 \%$ eugenol, $0.5 \%$ milk mineral, $0.5 \%$ phytate, $0.05 \%$ rosmarinic acid, $0.5 \%$ sodium tri poly phosphate (STPP) as compared to control. Day effect was seen $(\mathrm{P}<0.0001)$; no trt* day effect $(\mathrm{P}=0.965)$.

Table 7. $\mathrm{pH}$ values for raw ground poultry patties: time to first significant difference as compared to day 0 and means at day 0 and day 10 .

\begin{tabular}{|c|c|c|c|}
\hline \multirow{2}{*}{ Treatment } & \multirow{2}{*}{$\begin{array}{c}\text { Days to first } \\
\text { significant difference }^{A}\end{array}$} & \multicolumn{2}{|c|}{$\mathrm{pH}$} \\
\hline & & Day $0^{\mathrm{B}}$ & Day $10^{\mathrm{B}}$ \\
\hline Ground chicken & 10 & $6.18 \pm 0.23 \mathrm{a}$ & $6.64 \pm 0.26 a$ \\
\hline 0.05\% Eugenol & 10 & $6.17 \pm 0.16 \mathrm{a}$ & $6.62 \pm 0.35 a$ \\
\hline 0.5\% MM & ns & $6.17 \pm 0.14 \mathrm{a}$ & $6.50 \pm 0.19 a$ \\
\hline 0.5\% Phytate & ns & $6.48 \pm 0.21 \mathrm{a}$ & $6.80 \pm 0.84 \mathrm{a}$ \\
\hline $0.05 \%$ RA & 10 & $6.10 \pm 0.09 a$ & $6.60 \pm 0.34 a$ \\
\hline 0.5\% STPP & 10 & $6.37 \pm 0.16 \mathrm{a}$ & $6.76 \pm 0.32 \mathrm{a}$ \\
\hline
\end{tabular}

STPP = sodium tri-polyphosphate; RA = rosmarinic acid; $\mathrm{MM}=$ milk mineral. ${ }^{\mathrm{A}}$ : Time point where first significant difference $(\mathrm{P}<0.05)$ occurs as compared to initial reading for each meat system formulation. ${ }^{\mathrm{B}}$ : Values represent mean \pm standard deviation at a given time point $(\mathrm{n}=5$ ). Values sharing letters are not significantly different $(\mathrm{P}>0.05)$.

A significant positive correlation $(\mathrm{P}<0.001)$ between $\mathrm{L}^{*}$, $\mathrm{a}^{*}$, and $\mathrm{b}^{*}$ was observed in this study (Table 8 ) suggesting that all the values decreased consistently over time resulting in lighter and more green/brownish samples. A negative correlation between color and microbial growth was observed which indicates a constant increase in log cfu/g values with decreasing color. An inverse linear relationship between $\mathrm{pH}$ and color was seen suggesting an increase in $\mathrm{pH}$ in the samples may lead to decrease in color. The positive correlation $(\mathrm{r}=0.2378$; $\mathrm{P}<0.05$ ) between TBARS and $\mathrm{b} *$ indicates that an increase in lipid oxidation led to conditions that ultimately changed the color of samples to more yellow. This is consistent with previously reported results indicating specific lipid oxidation by-products are capable of forming adducts with $\mathrm{Mb}$, altering the shape of the protein shell and providing increased access of oxidizing molecules to the heme center [5].

\section{Conclusion}

The current study compared the effects of different antioxidants in raw poultry meat and it was observed that raw chicken was relatively more resistant to oxidative changes when compared to lipid oxidation values of raw beef and pork from other studies. Lower $\mathrm{pH}$ and total aerobic counts, consistent $\mathrm{MbO}_{2}$ to Met $\mathrm{Mb}$ ratio, and iron chelating ability of MM and other antioxidants contributed to the stability of chicken patties. Milk mineral was most effective in preventing lipid oxidation, minimal changes in $\mathrm{pH}$, and in maintaining the fresh color of chicken, but was not able to control growth of microorganisms. However, it is not known if an increased concentration of antioxidants can alter the results or how antioxidants work in cooked chicken and other ready-to-eat meats. Hence, assuming that many other factors can be responsible for major deterioration reaction and other changes in quality of meats, this subject requires further study.

\section{Acknowledgements}

This research was supported by the Utah Agricultural Experiment Station, Utah State University, and approved 
Table 8. Significant Pearson correlation coefficients (r-values) for meat system measurements.

\begin{tabular}{|c|c|c|c|c|}
\hline & Lightness (L*) & Redness $\left(a^{*}\right)$ & Yellowness (b*) & Chroma \\
\hline \multirow[t]{2}{*}{ TPC (log cfu/g) } & -0.28229 & -0.46289 & -0.41476 & -0.43127 \\
\hline & $\mathrm{P}<0.005$ & $\mathrm{P}<0.0001$ & $\mathrm{P}<0.0001$ & $\mathrm{P}<0.0001$ \\
\hline \multirow[t]{2}{*}{ Lightness (L*) } & & 0.39605 & 0.42469 & 0.441 \\
\hline & & $\mathrm{P}<0.0001$ & $\mathrm{P}<0.0001$ & $\mathrm{P}<0.0001$ \\
\hline \multirow[t]{2}{*}{ TBARS } & & & 0.2378 & 0.23674 \\
\hline & & & $\mathrm{P}<0.005$ & $\mathrm{P}<0.005$ \\
\hline \multirow[t]{2}{*}{ Yellowness (b*) } & & & & 0.99821 \\
\hline & & & & $\mathrm{P}<0.0001$ \\
\hline
\end{tabular}

as journal paper number 8823 .

\section{References}

[1] Blessing, M.H. and Müller, G. (1974) Myoglobin Concentration in the Chicken, Especially in the Gizzard (a Biochemical, Light and Electron Microscopic Study). Comparative Biochemistry and Physiology Part A: Physiology, 47, 535-540. http://dx.doi.org/10.1016/0300-9629(74)90017-6

[2] Fox, J.B. (1966) Chemistry of Meat Pigments. Journal of Agricultural and Food Chemistry, 14, 207-210. http://dx.doi.org/10.1016/0300-9629(74)90017-6

[3] Han, D., McMillin, K.W. and Godber, J.S. (1994) Hemoglobin, Myoglobin, and Total Pigments in Beef and Chicken Muscles: Chromatographic Determination. Journal of Food Science, 59, 1279-1282. http://dx.doi.org/10.1111/j.1365-2621.1994.tb14695.x

[4] Livingston, D.J. and Brown, W.D. (1981) The Chemistry of Myoglobin and Its Reactions [Meat Pigments, Food Quality Indices]. Food Technology, 38, 238-252.

[5] Naveena, B.M., Faustman, C., Tatiyaborworntham, N., Yin, S., Ramanathan, R. and Mancini, R.A. (2010) Detection of 4-Hydroxy-2-Nonenal Adducts of Turkey and Chicken Myoglobins Using Mass Spectrometry. Food Chemistry, 122, 836-840. http://dx.doi.org/10.1016/i.foodchem.2010.02.062

[6] Sánchez-Escalante, A., Djenane, D., Torrescano, G., Beltrán, J.A. and Roncalés, P. (2001) The Effects of Ascorbic Acid, Taurine, Carnosine and Rosemary Powder on Colour and Lipid Stability of Beef Patties Packaged in Modified Atmosphere. Meat Science, 58, 421-429. http://dx.doi.org/10.1016/S0309-1740(01)00045-6

[7] Bolumar, T., Andersen, M.L. and Orlien, V. (2011) Antioxidant Active Packaging for Chicken Meat Processed by High Pressure Treatment. Food Chemistry, 129, 1406-1412. http://dx.doi.org/10.1016/j.foodchem.2011.05.082

[8] Hernández, E.H., Ponce, E.A., Jaramillo, M.E.F. and Guerrero, I.L. (2009) Antioxidant Effect Rosemary (Rosmarinus officinalis L.) and Oregano (Origanum vulgare L.) Extracts on TBARS and Colour of Model Raw Pork Batters. Meat Science, 81, 410-417. http://dx.doi.org/10.1016/j.meatsci.2008.09.004

[9] Lee, K.G. and Shibamoto, T. (2001) Antioxidant Property of Aroma Extract Isolated from Clove Buds [Syzygium aromaticum (L.)]. Food Chemistry, 74, 443-448. http://dx.doi.org/10.1016/S0308-8146(01)00161-3

[10] Choe, E. and Min, D.B. (2006) Mechanisms and Factors for Edible Oil Oxidation. Comprehensive Reviews in Food Science and Food Safety, 5, 169-186. http://dx.doi.org/10.1111/j.1541-4337.2006.00009.x

[11] Vasavada, M.N., Dwivedi, S. and Cornforth, D. (2006) Evaluation of Garam Masala Spices and Phosphates as Antioxidants in Cooked Ground Beef. Journal of Food Science, 71, C292-C297. http://dx.doi.org/10.1111/j.1750-3841.2006.00039.x

[12] Genena, A.K., Hense, H., Smânia Jr., A. and de Souza, S.M. (2008) Rosemary (Rosmarinus officinalis): A Study of the Composition, Antioxidant and Antimicrobial Activities of Extracts Obtained with Supercritical Carbon Dioxide. Food Science and Technology, 28, 463-469. http://dx.doi.org/10.1590/s0101-20612008000200030

[13] Muraoka, S. and Miura, T. (2004) Inhibition of Xanthine Oxidase by Phytic Acid and Its Antioxidative Action. Life Sciences, 74, 1691-1700. http://dx.doi.org/10.1016/j.lfs.2003.09.040

[14] Allen, K. and Cornforth, D. (2007) Antioxidant Mechanism of Milk Mineral-High-Affinity Iron Binding. Journal of Food Science, 72, C078-C083. http://dx.doi.org/10.1111/j.1750-3841.2006.00199.x

[15] John, C. and Henry, M. (1967) Sodium Tripolyphosphate Granular Product. 
http://patft1.uspto.gov/netacgi/nph-Parser?patentnumber=3338671

[16] Tougan, P.U., Dahouda, M., Salifou, C.F.A., Ahounou, S.G.A., Kpodekon, M.T., Mensah, G.A. and Karim, I.Y.A. (2013) Conversion of Chicken Muscle to Meat and Factors Affecting Chicken Meat Quality: A Review. International Journal of Agronomy and Agricultural Research, 3, 1-20.

[17] Allen, K. and Cornforth, D. (2010) Comparison of Spice-Derived Antioxidants and Metal Chelators on Fresh Beef Color Stability. Meat Science, 85, 613-619. http://dx.doi.org/10.1016/j.meatsci.2010.03.012

[18] Bowen, W.J. (1949) The Absorption Spectra and Extinction Coefficients of Myoglobin. Journal of Biological Chemistry, 179, 235-245.

[19] Allen, K. and Cornforth, D. (2009) Effect of Chelating Agents and Spice-Derived Antioxidants on Myoglobin Oxidation in a Lipid-Free Model System. Journal of Food Science, 74, C375-C379. http://dx.doi.org/10.1111/j.1750-3841.2009.01170.x

[20] Hunt, M.C. (1991) Guidelines for Meat Color Evaluation. Proceedings of the 44th Reciprocal Meat Conference, Manhattan, 9-12 June 1991, American Meat Science Association, Savoy, 9-10.

[21] Buege, J.A. and Aust, S.D. (1978) Microsomal Lipid Peroxidation. Methods in Enzymology, 52, 302-310. http://dx.doi.org/10.1016/S0076-6879(78)52032-6

[22] Carpenter, C.E. and Clark, E. (1995) Evaluation of Methods Used in Meat Iron Analysis and Iron Content of Raw and Cooked Meats. Journal of Agricultural and Food Chemistry, 43, 1824-1827. http://dx.doi.org/10.1021/jf00055a014

[23] Folch, J., Lees, M. and Stanley, G.H.S. (1957) A Simple Method for the Isolation and Purification of Total Lipids from Animal Tissues. Journal of Biological Chemistry, 226, 497-509.

[24] Luna, A.M. (2011) A Simplified Chloroform-Methanol Method for the Quantitative Determination of Total Lipids in Meat and Poultry. Proceedings of the 35th National Nutrient Databank Conference, Bethesda, 8 April 2011.

[25] Jaspreet, A., David, H., Janet, R. and Pamela, P. (2014) Agricultural Research Service Report: USDA National Nutrient Databank for Food Composition (No. 8040-52000-064-00). USDA-ARS, Washington DC. http://www.ars.usda.gov/research/projects/projects.htm?ACCN_NO=426560

[26] National Chicken Council (2012) The Nutritional Value of Chicken. http://www.nationalchickencouncil.org/chicken-the-preferred-protein-for-your-health-and-budget/the-nutritional-valueof-chicken/

[27] International Commission on Illumination (1978) Recommendations on Uniform Color Spaces, Color-Difference Equations, Psychometric Color Terms. Vols. 1-CIE Publication No. 15, Vol. Supplement No. 2, Paris.

[28] Melvin, H. and Andy, K. (2012) Meat Color Measurement Guidelines. American Meat Science Association, Champaign.

[29] Turp, G.Y. and Serdaroğlu, M. (2004) The Effect of Ascorbic Acid, Rosemary Extract and $\alpha$-Tocopherol/Ascorbic Acid on Some Quality Characteristics of Chicken Patties Stored at $4^{\circ} \mathrm{C}$ for 7 Days. Journal of Food Science and Technology, 7, 153-157.

[30] Chouliara, E., Karatapanis, A., Savvaidis, I.N. and Kontominas, M.G. (2007) Combined Effect of Oregano Essential Oil and Modified Atmosphere Packaging on Shelf-Life Extension of Fresh Chicken Breast Meat, Stored at $4^{\circ} \mathrm{C}$. Food Microbiology, 24, 607-617. http://dx.doi.org/10.1016/j.fm.2006.12.005

[31] Jay, J.M. (1995) Intrinsic and Extrinsic Parameters of Foods That Affect Microbial Growth. In: Jay, J.M., Loessner, M.J. and Golden, D.A., Eds., Modern Food Microbiology, 6th Edition, Aspen Publishers, New York, 38-66. http://dx.doi.org/10.1007/978-1-4615-7476-7

[32] Min, B. and Ahn, D.U. (2009) Factors in Various Fractions of Meat Homogenates That Affect the Oxidative Stability of Raw Chicken Breast and Beef Loin. Journal of Food Science, 74, C41-C48. http://dx.doi.org/10.1111/j.1750-3841.2008.01003.x

[33] Pradhan, A.A., Rhee, K.S. and Hernández, P. (2000) Stability of Catalase and Its Potential Role in Lipid Oxidation in Meat. Meat Science, 54, 385-390. http://dx.doi.org/10.1016/S0309-1740(99)00114-X

[34] Allen, C.D., Fletcher, D.L., Northcutt, J.K. and Russell, S.M. (1998) The Relationship of Broiler Breast Color to Meat Quality and Shelf-Life. Poultry Science, 77, 361-366. http://dx.doi.org/10.1093/ps/77.2.361

[35] Harmayani, E., Sofos, J.N. and Schmidt, G.R. (1991) Growth and Aminopeptidase Activity of Pseudomonas fragi in Presence of Phosphates. Lebensmittel Wissenschaft Technologie, 24, 350-354. 